\title{
Cellular Physiology

\section{Differential Patterns of Local Gene Regulation in Crush Lesions of the Rat Optic and Sciatic Nerve: Relevance to Posttraumatic Regeneration}

\author{
Philipp Zickler*, Patrick Küry*, Michael Gliem, Hans-Peter Hartung \\ and Sebastian Jander
}

Department of Neurology, Heinrich-Heine-University, Düsseldorf, *These authors contributed equally to this study

\section{Key Words}

Nerve crush • Axon • Inflammation • Aquaporin 4 • Plasminogen activator

\begin{abstract}
Axon regrowth after nerve injury can occur in the peripheral but fails in the central nervous system. Cellular reactions at the lesion site affect axonal regrowth. We compared gene regulation in optic nerve (ON) and sciatic nerve (SN) crush lesions in adult rats by cDNA array analysis, quantitative RTPCR and immunohistochemistry, focusing on the primary lesion site rather than the proximal or distal nerve stump. Four days after injury, identical gene regulation in $\mathrm{ON}$ and $\mathrm{SN}$ lesions was found for 19/ 1185 genes (15 up, 4 down). In contrast, tissuespecific regulations were identified for 48 genes in $\mathrm{ON}$ and 50 genes in $\mathrm{SN}$ crush lesions. Among these, in the ON many genes were downregulated (23 up, 25 down) whereas upregulation predominated in SN lesions (43 up, 7 down), especially for signaling, metabolism, and translation/transcription-related genes. In $\mathrm{ON}$ lesions aquaporin 4 downregulation corresponded to a transient loss of astrocytes. Tissue-type plasminogen activator was upregulated
\end{abstract}

\section{KARGER}

Fax +4161306 1234

E-Mail karger@karger.ch

www.karger.com
(C) 2010 S. Karger AG, Basel

$1015-8987 / 10 / 0263-0483 \$ 26.00 / 0$

Accessible online at:

www.karger.com/cpb in the lesion and distal stump of $\mathrm{SN}$ while the urokinase-type plasminogen activator was upregulated only in the ON lesion indicating differences in local proteolysis between the systems. Typical neuronal genes were regulated at the crush site comprising neurotransmitter genes in $\mathrm{ON}$ and actin cytoskeleton-related genes in the SN. The differential orchestration of local gene regulation has implications for axonal regeneration in central nervous system lesions.

Copyright (C) 2010 S. Karger AG, Basel

\section{Introduction}

Axonal damage is a common consequence of traumatic and inflammatory damage to the nervous system causing severe and persistent disability in diseases such as spinal cord injury $[1,2]$ and multiple sclerosis $[3,4]$. The central and peripheral nervous systems differ fundamentally in their response to axonal injury. Transected axons spontaneously regrow beyond the site of injury in the peripheral nervous system (PNS) and achieve at least partial functional recovery. Contrastingly, in the central nervous system (CNS) abortive sprouting

Dr. Patrick Küry or Dr. Sebastian Jander

Department of Neurology, Heinrich-Heine-University

Moorenstr. 5, 40225 Düsseldorf (Germany)

Tel. +49-2118117822 (PK) or +49-2118118978 (SJ), Fax +49-(0)211-81-18485

E-Mail kuery@uni-duesseldorf.de or jander@uni-duesseldorf.de 
does not result in successful innervation of distal parts of injured fiber tracts.

Apart from the intrinsic neuronal growth capacity [5] the extent of axon regeneration depends on a permissive environment [6,7]. Differences in the glial response, inflammation, cytokine and growth factor release, clearance of myelin debris, and scar formation may contribute to the failure of the CNS to support axonal regeneration after injury $[8,9]$. Transcriptional profiling in models of axotomy has identified candidate genes which may contribute to axon regeneration. However, a direct comparison of local gene responses at PNS vs. CNS lesion sites has not been performed yet. We therefore compared local molecular responses in peripheral and central nerves at the site of crush injury with the aim to identify targets for novel therapies. Crush lesions of the optic nerve $(\mathrm{ON})$ and sciatic nerve $(\mathrm{SN})$ are well-defined models to compare axotomy-induced changes in the CNS and PNS, respectively. Furthermore, $\mathrm{ON}$ crush injury is of clinical relevance for ophthalmological diseases such as glaucoma and optic neuritis. We compared lesion-associated local transcriptional changes four days after $\mathrm{ON}$ and $\mathrm{SN}$ crush injury in adult Wistar rats by means of cDNA array hybridization analysis. This time point was chosen because macrophage recruitment as a critical prerequisite for tissue remodeling after injury is most pronounced at this stage. For selected genes, spatiotemporal patterns of gene regulation were further studied by real-time quantitative RT-PCR (Q-PCR) and immunohistochemistry.

\section{Materials and Methods}

\section{Animal experiments}

All animal experiments were performed in 8 to 10 weeks old male Wistar rats (250-300 g body weight) deeply anesthetized with enflurane in a $2: 1 \mathrm{~N}_{2} \mathrm{O} / \mathrm{O}_{2}$ atmosphere. The experimental protocol was in accordance with international guidelines of handling laboratory animals and had been approved by the institutional animal experimentation review committee. For SN crush, the right SN was exposed at midthigh level and crushed with a sterile forceps (Dumont \#2) for $60 \mathrm{sec}$ with maximal strength. After wound suturing, the animals were held at standard laboratory conditions. For intraorbital crush injury of the right ON the animals' head was positioned in a stereotactic frame. An incision was made through the temporal palpebral tissue and the lacrimal gland was largely removed. After mobilization of the eyeball the $\mathrm{ON}$ was exposed and crushed $2 \mathrm{~mm}$ posterior to the eyeball with a sterile forceps (Dumont \#5) for $30 \mathrm{sec}$ with maximal strength, always leaving the ophthalmic artery intact. All procedures were performed under visual control using a binocular dissection microscope.
After the nerve crush the eyeball was relocated and the wound was sutured. In both paradigms, ON or SN of control animals were exposed in parallel for a sham operation without applying the crush lesion.

For mRNA isolation and tissue preparation, rats were killed by an overdose of ether at days 2, 4, 7, 14 and 30 after operation. The crush site and the entire accessible distal nerve stump were prepared. The prepared nerve segments were chopped into pieces of approximately $2 \mathrm{~mm}$ length, and immediately stored in RNA later ${ }^{\mathrm{TM}}$ solution (Ambion). For the array analysis, the primary lesion site of $\mathrm{ON}$ and $\mathrm{SN}$ was isolated from $n=20$ rats per paradigm. Uncrushed controls were generated from $n=20 \mathrm{ON}$ and $n=25 \mathrm{SN}$ from sham-operated animals. For analysis by Q-PCR, tissue samples at days 2, 4, 7 and 14 post crush were collected from $n=5$ animals for each paradigm from both, the crush site and the distal nerve stump. For the array and Q-PCR analysis samples of $n=5$ animals were pooled, respectively, and total RNA was isolated using the TRIzol $^{\text {TM }}$ reagent (Life Sciences, Gaithersburg, MD, USA) according to the manufacturer's instructions and quantified spectrophotometrically. For immunohistochemistry, crushed $\mathrm{ON}$ and $\mathrm{SN}$ from $\mathrm{n}=3$ animals per condition and time point were prepared on days $2,4,7,14,30$ after crush injury, longitudinally embedded in Tissue-Tek mounting medium, snap frozen in isopentane precooled to $-50^{\circ} \mathrm{C}$ on dry ice, and stored at $-80^{\circ} \mathrm{C}$.

\section{cDNA array hybridization and analysis}

The array analyses were performed on $6 \mu \mathrm{g}$ pooled total RNA using Atlas rat 1.2 cDNA arrays (BD Biosciences/ Clontech, Heidelberg, Germany) essentially according to previously established procedures $[10,11]$. Total RNA was reverse transcribed with the array-specific rat 1.2 CDS primer mix in the presence of $\left[\alpha^{32} \mathrm{P}\right]$-dATP and the MMLV reverse transcriptase (BD Biosciences/Clontech). The hybridization procedure and washing steps were performed according to the manufacturer's protocol. Hybridized arrays were exposed to phosphoimaging screens, scanned [BAS-1500 reader (Fujifilm); Raytest, Straubenhardt, Germany] and digitalized for analysis and quantification with the image analysis software AIDA Array Metrix 3.0 (Raytest). Signals were normalized using the average signal intensity of all expressed genes as reference. For the ON crush cohort 4 individual datasets from lesioned and sham operated ONs were collected. In the SN crush paradigm $n=4$ datasets from lesioned nerves were compared to $\mathrm{n}=5$ array hybridizations from sham operated nerves. Accordingly, $16 \mathrm{ON}$ and $20 \mathrm{SN}$ cross-comparison datasets were obtained for gene expression analysis. Only genes showing a significant regulation, i.e. at least twofold altered expression levels, in more than two-thirds of the comparison datasets (11/ 16 for $\mathrm{ON}$ and 14/20 for SN comparisons) were considered to be regulated and consecutively used to calculate the mean regulation factor for each individual gene. For further control, array filter hybridization dots were visually inspected in order to confirm the results.

Quantitative real time PCR ( $Q-P C R)$

Real time Q-PCR was performed for validation of the array results on the same mRNA samples as used for the array analysis 


\begin{tabular}{|c|c|c|c|c|c|c|c|c|}
\hline \multirow{3}{*}{$\begin{array}{l}\text { FUNCTION } \\
\text { growth / } \\
\text { differentiation }\end{array}$} & \multirow{2}{*}{$\begin{array}{c}\text { GenBank } \\
\text { number }\end{array}$} & GENE NAME & \multicolumn{3}{|c|}{\begin{tabular}{ll}
\multicolumn{3}{c}{ OPTIC NERVE } \\
average regul. & datasets \\
up down & max. 16
\end{tabular}} & \multicolumn{3}{|c|}{\begin{tabular}{ll}
\multicolumn{2}{c}{ SCIATIC NERVE } \\
average regul. & datasets \\
up down & max. 20
\end{tabular}} \\
\hline & & TGF -beta receptor type 1 precursor & 5,0 & & 13 & 5,6 & & 20 \\
\hline & X52498 & TGF -beta 1 & 2,5 & & 16 & 5,6 & & 15 \\
\hline trafficking / & U13253 & fatty acid -binding protein (epidermal) & 4,9 & & 16 & 4,9 & & 16 \\
\hline metabolism & $\mathrm{J} 04526$ & hexokinase type I & & $-3,1$ & 13 & & $-2,6$ & 17 \\
\hline ion channel & M26161 & voltage -gated potassium channel KV1.1 & & $-4,9$ & 15 & & $-4,1$ & 17 \\
\hline \multirow{6}{*}{$\begin{array}{l}\text { inflammation / } \\
\text { chem otaxis }\end{array}$} & U54791 & CXCR4 & 7,5 & & 16 & 15,9 & & 20 \\
\hline & AB003042 & C5a anaphylatoxin chemotactic receptor & 7,1 & & 16 & 4,6 & & 17 \\
\hline & M57276 & leukocyte antigen CD53 (MRC -OX44) & 4,7 & & 16 & 2,8 & & 15 \\
\hline & U04740 & platelet -activating factor receptor & 3,5 & & 16 & 4,6 & & 18 \\
\hline & U77776 & IL-18 & 2,9 & & 13 & 2,7 & & 16 \\
\hline & U38376 & cytosolic phospholipase A2 & 2,3 & & 12 & 3,3 & & 17 \\
\hline \multirow[t]{4}{*}{ proteolysis } & X82396 & cathepsin B & 7,6 & & 16 & 3,4 & & 16 \\
\hline & X54467 & cathepsin D & 7,0 & & 16 & 7,1 & & 20 \\
\hline & Y00697 & cathepsin L & 3,3 & & 15 & 3,1 & & 16 \\
\hline & M58593 & proteasome component $\mathrm{C} 8$ & 2,7 & & 14 & 4,6 & & 16 \\
\hline \multirow[t]{2}{*}{ transcription } & Z46372 & DNA topoisomerase II alpha & 4,5 & & 16 & 26,0 & & 20 \\
\hline & D84418 & high mobility group protein 2 & 3,6 & & 11 & 3,1 & & 19 \\
\hline \multirow[t]{2}{*}{ myelination } & U31367 & myelin protein MVP17 & & $-6,4$ & 16 & & $-13,7$ & 20 \\
\hline & M25889 & myelin basic protein $\mathrm{S}$ (MBP S) & & $-2,9$ & 12 & & $-8,5$ & 20 \\
\hline
\end{tabular}

Table 1. Genes with a common regulation pattern in both lesion types 4 days after nerve crush injury were predominantly upregulated (15 out of 19 genes). In the array analysis significant gene regulation was defined by more than twofold expression changes in more than two-thirds out of 16 optic or 20 sciatic nerve crush datasets cross-compared with sham-operated nerves. For each gene the average up- or downregulation and number of cross-comparison datasets with significant regulation were listed for the optic and sciatic nerve, respectively.

at day 4 and for time course analysis on additionally isolated mRNA from days 2, 4, 7 and 14 post crush. Total RNA was reverse transcribed using Superscript II enzyme (Invitrogen, Carlsbad, CA) and dT19(A/C/G) oligonucleotide primers as described previously [12]. According to the manufacturer's instructions cDNA samples were analyzed on an ABI 5700 Sequence Detection System (Applied Biosystems, Darmstadt, Germany) using the Sybr Green Universal Master Mix (Applied Biosystems). Glyceraldehyde 3-phosphate dehydrogenase was used as reference gene. Primer sequences were designed using the PrimerExpress 2.0 software (Applied Biosystems) and tested for the generation of specific amplicons. The forward and reverse primer sequences used were: aquaporin 4 (TGC TGG CAG GTG CAC TTT AC; TGA GCT CCA CGT CAG GAC AG), glyceraldehyde 3-phosphate dehydrogenase (GAA CGG GAA GCT CAC TGG C; GCA TGT CAGATC CACAAC GG), glial cell line-derived neurotrophic factor receptor alpha (CTC AGC AGC ATT GCC TTC TG; TGT CAT TCA CAC TAG GCT GCG), insulin-like growth factor I (IGF) (CAC GTC ACC GCA AGA TCC TT; TTC CGA TGT TTT GCA GGT TG), IGF-binding protein 3 (GGT GCG TGG ACA AGT ACG G; TCC CCT TGG TGT CAT AGC CT), neuropeptide Y (NPY) (GAA ACC AGT CTG CCT GTC CC; GGAATC CAG CCT GGT GGT G), tissuetype plasminogen activator (tPA) (GCC CCC TAA AAC CCT TGA AA; TGA GGA TTG TGG GAG GAT GG), urokinase-type plasminogen activator (uPA) (CAC TCA TCC CCA CGC TGA C; ACA TGA TGG AGA TGA CCC TGC), thymosin-beta 15 (GCT GCG GAC AGA ATT GCT G; CTT GAC TGC TCG TTC CAA AGC), thyrotropin-releasing hormone (TRH) (TCT GTA

Local Gene Regulation in Nerve Regeneration

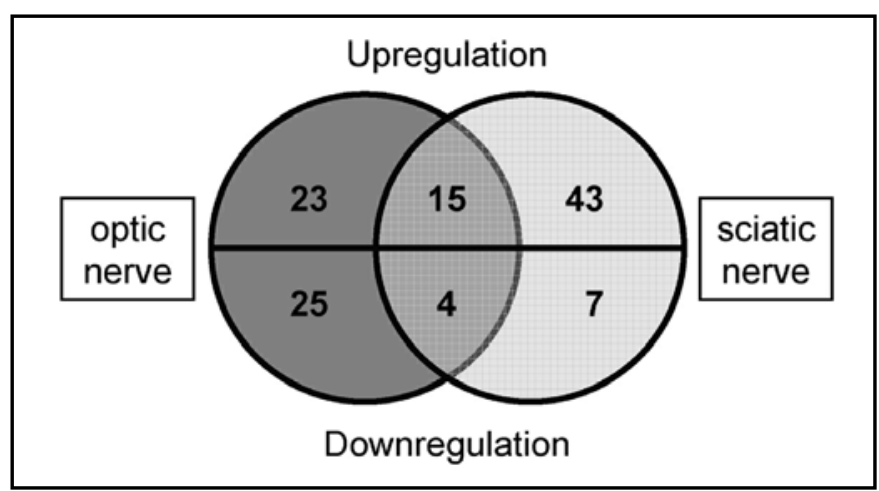

Fig. 1. Overall distribution of significantly regulated genes in the array analysis 4 days after nerve crush. Upregulation clearly predominated for genes regulated selectively in the sciatic nerve lesion (right) and in both tissue-types (overlap in the middle) in contrast to the optic nerve (left) where downregulated genes closely outnumbered upregulation.

ATC TGC CCC ATG TGG; ATG CGC TGAAGC TAT ACC AGG). Relative gene expression levels were determined according to the manufacturer's $\Delta \Delta \mathrm{Ct}$ method. Each sample was analyzed in two independent Q-PCR reactions and the results were calculated as mean values and standard error of the mean.

Immunohistochemistry

Serial adjacent cryostat sections $(10 \mu \mathrm{m})$ of crushed ON and $\mathrm{SN}$ were fixed in $4 \%$ paraformaldehyde in phosphate- 


\begin{tabular}{|c|c|c|c|c|c|c|c|c|}
\hline & & OPTIC NERVE & & & & SCIATIC NERVE & & \\
\hline FUNCTION & $\begin{array}{l}\text { GenBank } \\
\text { number }\end{array}$ & GENE NAME & $\begin{array}{l}\text { average } \\
\text { regul. }\end{array}$ & $\begin{array}{l}\text { datasets } \\
\max .16\end{array}$ & $\begin{array}{c}\text { GenBank } \\
\text { number }\end{array}$ & GENE NAME & $\begin{array}{l}\text { average } \\
\text { regul. }\end{array}$ & $\begin{array}{l}\text { datasets } \\
\max .20\end{array}$ \\
\hline $\begin{array}{l}\text { growth / } \\
\text { differentiation }\end{array}$ & $\begin{array}{l}\text { M15480 } \\
\text { M13750 }\end{array}$ & $\begin{array}{l}\text { insulin like growth factor I (IGF) } \\
\text { prolactine like protein A (rPLP-A) }\end{array}$ & $\begin{array}{r}6,4 \\
-3,8\end{array}$ & $\begin{array}{l}13 \\
12\end{array}$ & $\begin{array}{l}\text { U97142 } \\
\text { M89791 } \\
\text { M31837 } \\
\text { M18416 }\end{array}$ & $\begin{array}{l}\text { GDNF receptor alpha } \\
\text { IGF binding protein } 1 \text { precursor } \\
\text { IGF binding protein } 3 \text { precursor } \\
\text { NGF-induced protein } 1 \text { (NGFI-A) }\end{array}$ & $\begin{array}{l}9,4 \\
7,2 \\
3,2 \\
3,2\end{array}$ & $\begin{array}{l}20 \\
17 \\
20 \\
14\end{array}$ \\
\hline $\begin{array}{l}\text { trafficking/ } \\
\text { metabolism }\end{array}$ & $\begin{array}{l}\text { D13871 } \\
\text { D10041 } \\
\text { U88036 } \\
\text { M95591 } \\
\text { D63834 } \\
\text { X06984 } \\
\text { U25651 } \\
\text { U02096 }\end{array}$ & $\begin{array}{l}\text { fructose (glucose) transporter } \\
\text { long-chain fatty acid-CoA ligase } \\
\text { brain-specific organic anion transporter } \\
\text { squalene synthetase } \\
\text { monocarboxylate transporter } \\
\text { aldolase C } \\
\text { muscle 6-phosphofructokinase } \\
\text { fatty acid-binding protein (brain) }\end{array}$ & $\begin{array}{r}3,0 \\
-11,0 \\
-7,9 \\
-4,0 \\
-3,8 \\
-3,7 \\
-2,8 \\
-2,4\end{array}$ & $\begin{array}{l}15 \\
14 \\
15 \\
15 \\
15 \\
13 \\
12 \\
12\end{array}$ & $\begin{array}{l}\text { D10874 } \\
\text { D10952 } \\
\text { L12380 } \\
\text { M35052 } \\
\text { D10854 } \\
\text { U75581 } \\
\text { M12919 }\end{array}$ & $\begin{array}{l}\text { vacuolar ATP synthase (16-kDa) } \\
\text { cytochrome c oxidase (COX5B) } \\
\text { ADP-ribosylation factor } 1 \text { (ARF1) } \\
\text { mitochondrial ATP synthase B } \\
\text { aldehyde reductase } \\
\text { fatty acid- binding protein (adipocyte) } \\
\text { aldolase A }\end{array}$ & $\begin{array}{lr}6,3 & \\
6,2 & \\
4,4 & \\
4,0 & \\
3,1 & \\
& -5,4 \\
& -3,5\end{array}$ & $\begin{array}{l}20 \\
19 \\
20 \\
16 \\
16 \\
20 \\
20\end{array}$ \\
\hline motility & U60096 & integrin beta 4 precursor & $-2,9$ & 14 & $\begin{array}{l}\text { U25684 } \\
\text { U06755 }\end{array}$ & $\begin{array}{l}\text { thymosin beta } 15 \\
\text { acidic calponin }\end{array}$ & $\begin{array}{l}6,7 \\
2,7\end{array}$ & $\begin{array}{l}18 \\
15\end{array}$ \\
\hline ion channel & $\begin{array}{l}\mathrm{J} 04629 \\
\mathrm{M} 14512\end{array}$ & $\begin{array}{l}\mathrm{Na} / \mathrm{K} \text {-transp. ATPase (A TP1B2) } \\
\mathrm{Na} / \mathrm{K} \text { ATPase, alpha }(+ \text { ) isoform }\end{array}$ & $\begin{array}{l}-4,4 \\
-2,9\end{array}$ & $\begin{array}{l}16 \\
12\end{array}$ & & & & \\
\hline signal transduction & $\begin{array}{l}\text { M36317 } \\
\text { M20373 } \\
\text { J03624 } \\
\text { U55192 } \\
\text { M33962 } \\
\text { L06482 } \\
\text { AF005099 } \\
\text { M91590 } \\
\text { M95735 } \\
\text { X57764 } \\
\text { M88595 } \\
\text { M17527 } \\
\text { L35921 } \\
\text { U02983 } \\
\text { L14851 }\end{array}$ & $\begin{array}{l}\text { thyrotropin-releasing hormone (TRH) } \\
\text { neuropeptide Y (NPY) precursor } \\
\text { neuropeptide Y (NPY) } \\
\text { inositol phosphatase (SHIP) } \\
\text { neuronal pentraxin receptor } \\
\text { retinoid X receptor alpha } \\
\text { protein tyrosine phosphatase (PTPase) } \\
\text { beta-arrestin } 2 \text { (ARRB2) } \\
\text { syntaxin B } \\
\text { endothelin receptor (ET-B) } \\
\text { glycine transporter } \\
\text { adenylate cyclase-inhibit. G prot. } \\
\text { GTP-bind.protein G(i)/G(s)/G(o) } \\
\text { secretogranin } 3(\mathrm{Sg} 3) \\
\text { neurexin III-alpha }\end{array}$ & $\begin{array}{r}24,8 \\
8,4 \\
3,5 \\
6,4 \\
3,0 \\
2,6 \\
2,6 \\
2,5 \\
-7,7 \\
-5,9 \\
-4,5 \\
-3,3 \\
-2,7 \\
-2,5 \\
-2,5\end{array}$ & $\begin{array}{l}16 \\
16 \\
13 \\
14 \\
12 \\
14 \\
11 \\
11 \\
13 \\
14 \\
16 \\
13 \\
13 \\
11 \\
11\end{array}$ & $\begin{array}{l}\text { D38222 } \\
\text { L13151 } \\
\text { M95738 } \\
\text { M96601 } \\
\text { M85299 } \\
\text { M17525 } \\
\text { D17445 } \\
\text { M20637 } \\
\text { D38224 } \\
\text { L20822 }\end{array}$ & $\begin{array}{l}\text { tyrosine phosphatase-like protein } \\
\text { ras-GTPase-activating protein } \\
\text { Na/Cl- dependent GABA transporter } 3 \\
\text { taurine transporter } \\
\text { sodium/hydrogen exchange prot.1 } \\
\text { GTP-binding protein (G-alpha-8) } \\
\text { PKC inhibitor protein-1 } \\
\text { phospholipase C delta } 1 \text { (PLC-III) } \\
\text { annexin IV (ANX4) } \\
\text { syntaxin } 5 \text { (STX5) }\end{array}$ & 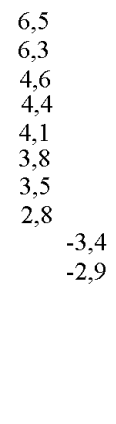 & $\begin{array}{l}20 \\
18 \\
19 \\
19 \\
17 \\
16 \\
16 \\
15 \\
16 \\
20\end{array}$ \\
\hline $\begin{array}{l}\text { inflammation } \\
\text { chemotaxis }\end{array}$ & $\begin{array}{l}\text { X69903 } \\
\text { M10072 } \\
\mathrm{U} 22414\end{array}$ & $\begin{array}{l}\text { IL-4 receptor } \\
\text { leukocyte common antigen precursor } \\
\text { MIP-1alpha }\end{array}$ & $\begin{array}{l}4,0 \\
3,8 \\
3,6\end{array}$ & $\begin{array}{l}16 \\
16 \\
13\end{array}$ & $\begin{array}{l}\text { X16956 } \\
\text { U73142 } \\
\text { M92340 } \\
\text { M64986 }\end{array}$ & $\begin{array}{l}\text { beta-2-microglobulin } \\
\text { MAP kinase p38 } \\
\text { IL-6 receptor beta chain } \\
\text { high mobilitiy group protein } 1\end{array}$ & $\begin{array}{l}7,5 \\
3,4 \\
3,3 \\
2,8\end{array}$ & $\begin{array}{l}14 \\
14 \\
16 \\
14\end{array}$ \\
\hline proteolysis & $\begin{array}{l}\text { X63434 } \\
\text { D90404 } \\
\text { M24067 } \\
\text { AF010306 } \\
\text { D50694 } \\
\text { M32247 }\end{array}$ & $\begin{array}{l}\text { urokinase plasminogen activator ( } \mathrm{UPA}) \\
\text { cathepsin } \mathrm{C} \\
\text { plasminogen activator inhibitor } 1 \text { (PAI-1) } \\
\text { cathepsin } \mathrm{K} \\
26 \mathrm{~S} \text { protease regulatory subunit } 7 \\
\text { alpha- } 1 \text { antitrypsin }\end{array}$ & $\begin{array}{r}23,5 \\
4,3 \\
3,7 \\
2,9 \\
2,1 \\
\quad-4,0\end{array}$ & $\begin{array}{l}16 \\
16 \\
14 \\
15 \\
11 \\
11\end{array}$ & $\begin{array}{l}\text { M65253 } \\
\text { L31883 } \\
\text { M23697 } \\
\text { X52783 } \\
\text { M61142 } \\
\text { U62897 }\end{array}$ & $\begin{array}{l}\text { matrix metalloproteinase (MMP10) } \\
\text { tissue inhibitor of metalloproteinase }-1 \\
\text { tissue-type plasminoge } n \text { activator (tPA) } \\
\text { proteasome subunit C5 } \\
\text { thimet oligopeptidase (THOP1) } \\
\text { carboxypeptidase D }\end{array}$ & $\begin{array}{l}6,9 \\
4,2 \\
3,8 \\
3,3 \\
3,0 \\
2,8\end{array}$ & $\begin{array}{l}14 \\
14 \\
17 \\
16 \\
16 \\
16\end{array}$ \\
\hline stress response & $\begin{array}{l}\text { X62404 } \\
Z 27118 \\
\text { U14007 } \\
\text { AF007775 } \\
\text { S } 83436 \\
\text { X62660 }\end{array}$ & $\begin{array}{l}\text { glutathione peroxidase (epididymal) } \\
\text { heat shock protein } 70 \mathrm{k}-\mathrm{Da} \text { (HSP70) } \\
\text { aquaporin } 4 \text { (AQP4) } \\
\text { aquaporin } 8 \\
\text { glutahione S-transferase subunit } 13 \\
\text { glutathione transferase subunit } 8\end{array}$ & $\begin{array}{r}2,9 \\
2,3 \\
-15,2 \\
-5,4 \\
-2,9 \\
-2,6\end{array}$ & $\begin{array}{l}11 \\
11 \\
16 \\
11 \\
12 \\
12\end{array}$ & $\begin{array}{l}\text { L15079 } \\
\text { L22191 } \\
\text { S68987 } \\
\text { L38615 } \\
\text { X02904 }\end{array}$ & $\begin{array}{l}\text { multidrug resistance protein } 2 \text { (MDR2) } \\
\text { GLU-CYS ligase regulatory subunit } \\
\text { SET alpha + beta isoform } \\
\text { glutathione synthetase } \\
\text { glutathione S-transferase P subunit }\end{array}$ & $\begin{array}{l}5,3 \\
4,9 \\
4,0 \\
3,5 \\
2,9\end{array}$ & $\begin{array}{l}19 \\
17 \\
15 \\
16 \\
15\end{array}$ \\
\hline cell cycle/apoptosis & $\begin{array}{l}\text { X64589 } \\
\text { U05341 } \\
\text { M64723 }\end{array}$ & $\begin{array}{l}\mathrm{G} 2 / \mathrm{M} \text {-specific cyclin } \mathrm{B} 1 \\
\mathrm{p} 55 \mathrm{cdc} \\
\text { clusterin (CLU) }\end{array}$ & $\begin{array}{l}3,9 \\
2,7 \\
\quad-3,6\end{array}$ & $\begin{array}{l}16 \\
15 \\
14\end{array}$ & $\begin{array}{l}\text { D14014 } \\
\text { D16309 }\end{array}$ & $\begin{array}{l}\text { G1/S-specific cyclin D1 } \\
\text { G1/S-specific cyclin D3 }\end{array}$ & $\begin{array}{l}8,6 \\
8,0\end{array}$ & $\begin{array}{l}20 \\
20\end{array}$ \\
\hline transcription & & & & & $\begin{array}{l}\text { L29259 } \\
\text { L20681 }\end{array}$ & $\begin{array}{l}\text { elongation factor SIII P15 subunit } \\
\text { c-ets-1 proto-oncogene protein }\end{array}$ & $\begin{array}{l}5,0 \\
3,2\end{array}$ & $\begin{array}{l}19 \\
16\end{array}$ \\
\hline translation & $\mathrm{X} 14210$ & ribosomal protein $\mathrm{S} 4$ & 2,4 & 12 & $\begin{array}{l}\text { X53504 } \\
\text { K03250 } \\
\text { X51707 } \\
\text { J02646 }\end{array}$ & $\begin{array}{l}\text { ribosomal protein L12 } \\
40 \text { S ribosomal protein } \mathrm{S} 11 \\
40 \mathrm{~S} \text { ribosomal protein } \mathrm{S} 19 \\
\text { translation initiation factor } 2 \text { alpha }\end{array}$ & $\begin{array}{l}4,8 \\
4,3 \\
3,3 \\
2,9\end{array}$ & $\begin{array}{l}14 \\
16 \\
16 \\
15\end{array}$ \\
\hline myelination & U62803 & lecithin cholesterol acyltransferase (LCAT) & $-7,1$ & 12 & $\begin{array}{l}\text { D17512 } \\
\text { U07683 } \\
\text { M69139 } \\
\text { K03242 }\end{array}$ & $\begin{array}{l}\text { cysteine-rich protein } 2 \\
\text { cerebroside synthase } \\
\text { peri pheral myelin protein } 22 \text { (PMP22) } \\
\text { myelin P0 protein precursor (P0) }\end{array}$ & $\begin{array}{r}2,4 \\
-7,5 \\
-6,5 \\
-4,1\end{array}$ & $\begin{array}{l}15 \\
16 \\
20 \\
16\end{array}$ \\
\hline
\end{tabular}

Table 2. Genes with tissue-specific expression and regulation ( $>$ twofold, in $>2 / 3$ of the cross-comparison datasets) at the lesion site 4 days after nerve crush were listed for the optic and sciatic nerve, respectively. Within functional categories the genes were ranked according to their average up- or downregulation and the respective number of significant cross-comparison datasets.

buffered saline for $10 \mathrm{~min}$ at $4^{\circ} \mathrm{C}$, followed by acetone $50 / 100 /$ $50 \%, 2$ minutes each at $4{ }^{\circ} \mathrm{C}$. After 30 min incubation with $0.3 \%$ $\mathrm{H}_{2} \mathrm{O}_{2}$ nonspecific binding sites were blocked with $3 \%$ normal horse or goat serum in PBS for $30 \mathrm{~min}$ at room temperature according to the primary antibody used. Serial sections were incubated overnight at $4{ }^{\circ} \mathrm{C}$ with a mouse mAb ED 1 against 
Fig. 2. Results from the array analysis 4 days after nerve crush were confirmed and further quantified by real-time PCR on the same mRNA samples. Representative genes with specific regulation in the optic nerve (left column) and sciatic nerve (right column) are shown with the results of the array hybridization and Q-PCR at the lesion site and additionally in the distal nerve stump. Significant up- or downregulation was defined by a more than 2-fold expression change (dashed line) relative to sham levels. Each Q-PCR was repeated twice and the mean and standard error of the mean were calculated. GDNF, glial cell line-derived neurotrophic factor; IGF, insulin-like growth factor.

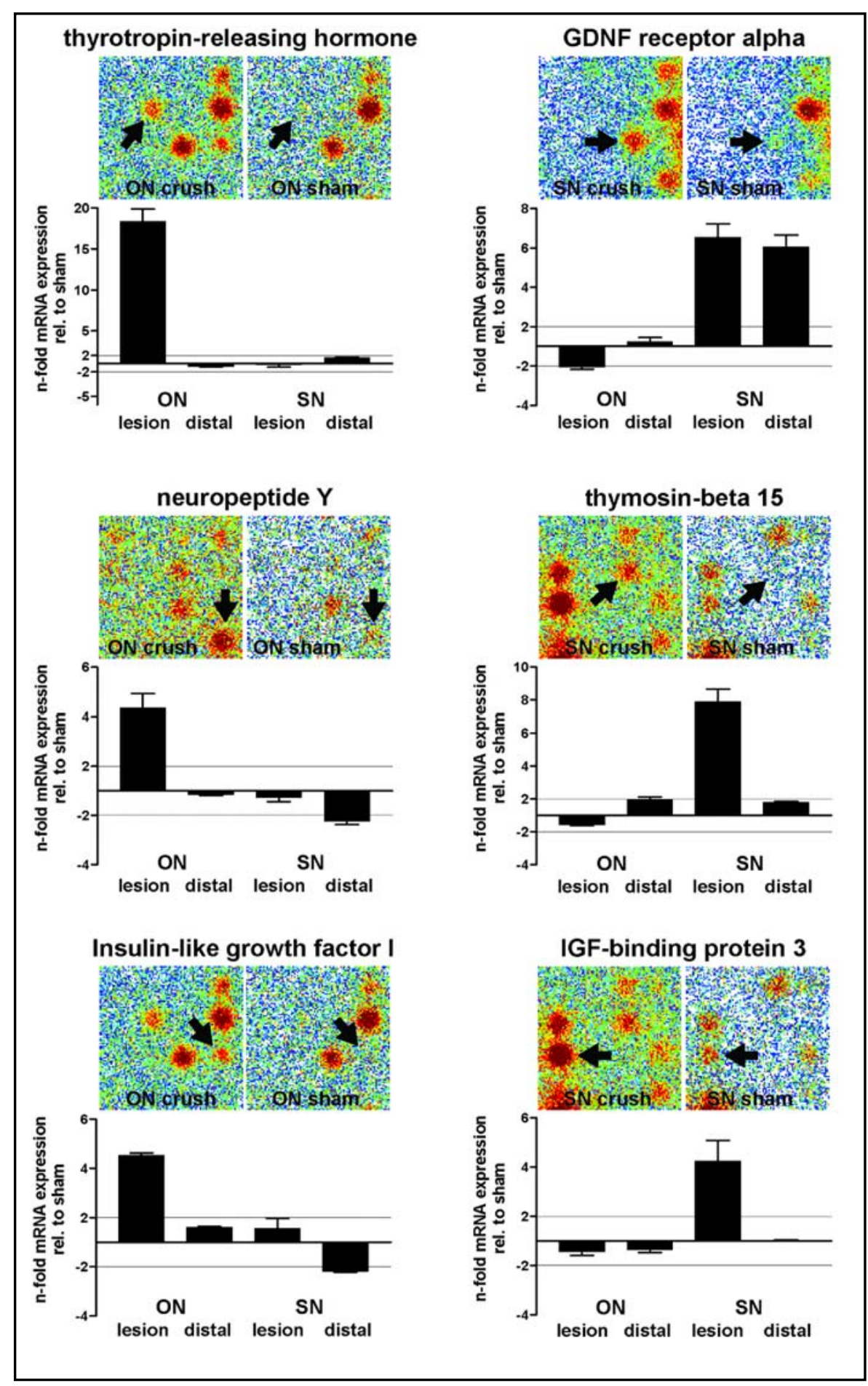

phagocytic macrophages (1:2000; Serotec, Oxford, UK), a mouse monoclonal glial fibrillary acidic protein (GFAP) antibody (1:500; Chemicon, CA, USA) against astrocytes, and a polyclonal antibody against the water channel aquaporin 4 (1:500; Sigma, MO, USA) followed by corresponding secondary antibody incubation and detection by the Vectastain ABC Elite kit reagents (Vector Laboratories, CA, USA) with diaminobenzidine as substrate according to the manufacturer's protocol.

Double labeling immunofluorescence was performed for GFAP and AQP4 using fluorochrome-conjugated secondary antibodies instead of the ABC kit reagents (Alexa 488- conjugated goat anti-mouse IgG for GFAP; Alexa 594conjugated goat anti-rabbit IgG for AQP4; both from Molecular Probes, Eugene, OR, USA).

\section{Results}

Array analysis: Overall quantitative aspects

In the array analysis, we found a roughly similar number of significantly regulated genes in $\mathrm{ON}$ (67 out of 


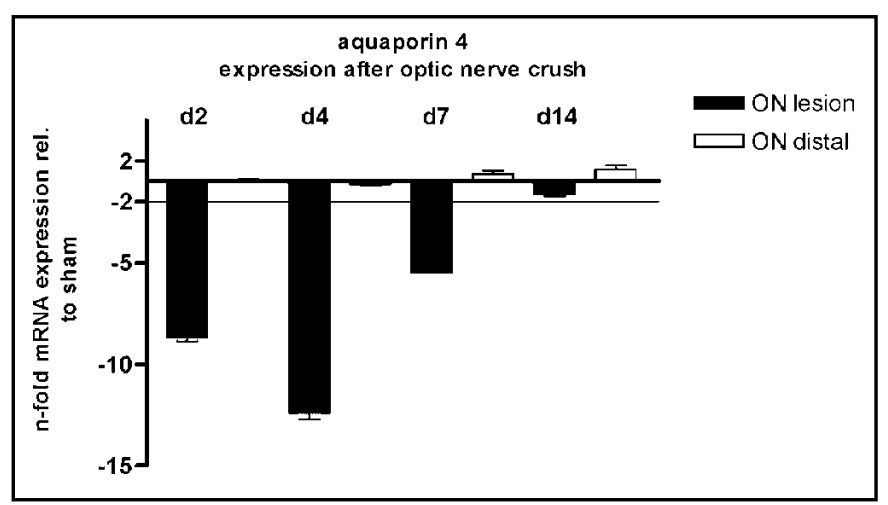

Fig. 3. Aquaporin 4 gene expression changes in the optic nerve $(\mathrm{ON})$ lesion and distal nerve stump relative to shamoperated nerves. Each Q-PCR was repeated twice at days 2, 4, 7 and 14 post nerve crush and the mean and standard error of the mean were calculated.

1185 genes, corresponding to $5.7 \%$ of all genes represented on the array filter) and SN lesions (69/1185 genes, $5.8 \%$ ), respectively.

A total of 19 genes, corresponding to $28 \%$ of all gene expression changes, showed an identical regulation pattern in ON and SN injury (Fig. 1, Table 1). Upregulation was found in more than $75 \%$ of these uniformly regulated genes $(15 / 19)$ and comprised genes related to inflammation (Interleukin-18, cytosolic phospholipase), chemotaxis (CXCR4, C5a receptor), and proteolysis (cathepsins B, D, and L). Only four genes were uniformly downregulated in both paradigms. In line with previous findings, downregulated genes mainly represented myelin genes [13] as well as the juxtaparanodal voltage gated potassium channel [14] thereby validating our experimental approach.

In contrast to the uniformly regulated genes, systemspecific expression changes were identified for 48 genes in $\mathrm{ON}$ and 50 genes in SN crush lesions (Fig. 1, Table 2). Among these differentially regulated genes, upregulation predominated in SN lesions (43 up, 7 down) whereas many more downregulated genes were identified in the ON (23 up, 25 down). System-specific gene regulation was most frequently observed in the categories of signal transduction, trafficking and metabolism, but also prominent for some genes related to growth and differentiation, proteolysis, and stress response (Table 2).

System-specific gene regulation studied by $Q-$ PCR

Representative genes showing differential regulation in ON and SN tissue were further studied by means of Q-PCR. Among the ON-specific regulated genes

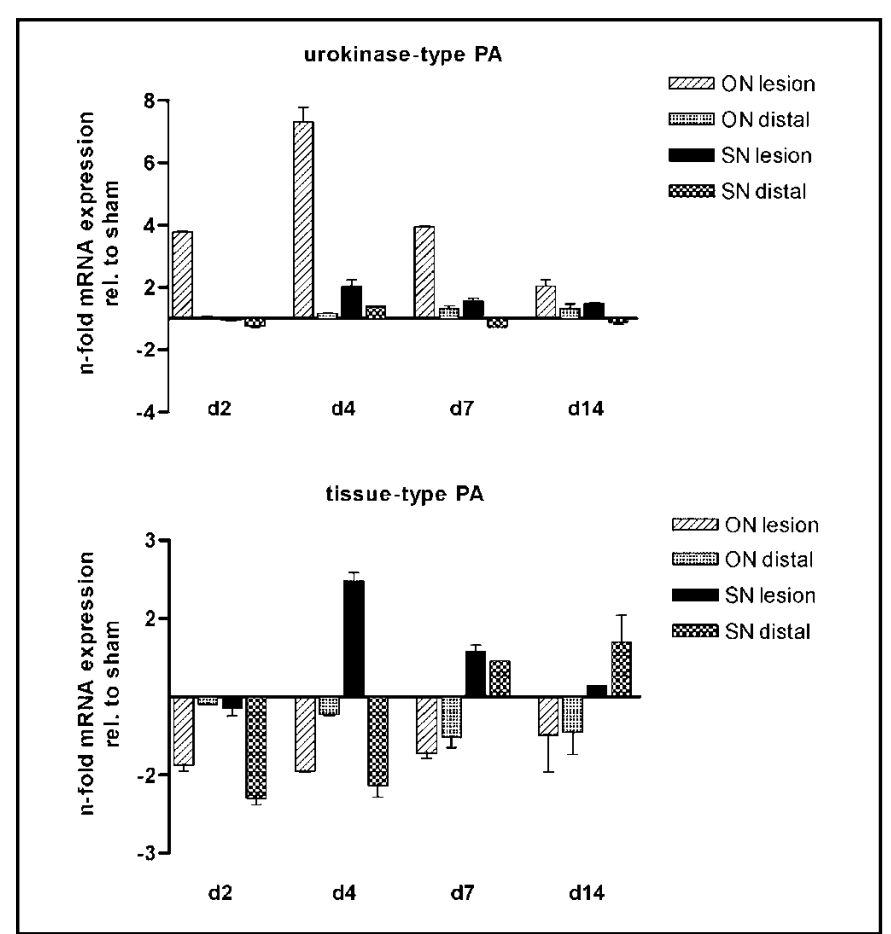

Fig. 4. Gene regulation for the urokinase- and tissue-type plasminogen activators (PA) were quantified at the lesion site and the distal nerve stump at days 2, 4, 7 and 14 post sciatic nerve $(\mathrm{SN})$ and optic nerve $(\mathrm{ON})$ crush by Q-PCR. The mean and standard error of the mean of duplicate Q-PCR results are shown in $n$-fold relation to sham-operated nerves, respectively.

particular strong upregulation was found for TRH and somewhat weaker induction for NPY and IGF-I (Fig. 2). Of note, Q-PCR confirmed reciprocal induction of IGFI and IGF-binding protein 3 (IGFBP-3) in ON and SN crush injury, respectively, with 4-5 fold induction of IGFI in the optic nerve lesion whereas IGFBP-3 was selectively induced in the SN model. In addition to the crush site, we also analyzed mRNA expression in the distal nerve stump. We found that all gene changes in the ON were restricted to the crush site whereas gene regulation in the SN to some extent involved the distal nerve stump as well.

The glial cell line-derived neurotrophic factor (GDNF) receptor alpha was studied as a growth factorrelated gene showing exclusive induction in the $\mathrm{SN}$ crush model. Q-PCR analysis (Fig. 2) confirmed a 6-fold upregulation at the crush site. GDNF receptor alpha upregulation occurred to a similar extent in the degenerating distal nerve stump. In contrast, the cytoskeleton-related gene thymosin-beta 15 and IGFBP3 as further examples of $\mathrm{SN}$-specific gene regulation were exclusively induced at the crush site but remained absent from the distal nerve stump.

Zickler/Küry/Gliem/Hartung/Jander 
Fig. 5. Immunohistochemistry of the crushed optic nerve showed oedematous swelling at the lesion site at day 4 after injury with strong infiltration by ED1 positive activated macrophage/microglia at days 7 to 14 , subsiding at day 30. At the inflamed lesion site aquaporin 4 (AQP4) reactivity was strongly decreased and paralleled by the loss of glial fibrillary acidic protein (GFAP) positive astrocytes. At day 30 AQP4 and GFAP positive astrocytes reappeared. Serial adjacent cryostat sections $(10 \mu \mathrm{m})$. Bottom row: Immunfluorescence double labeling showing coexpression of AQP4 and GFAP in astrocytes at a perilesional site of an optic nerve (day 4 after injury).

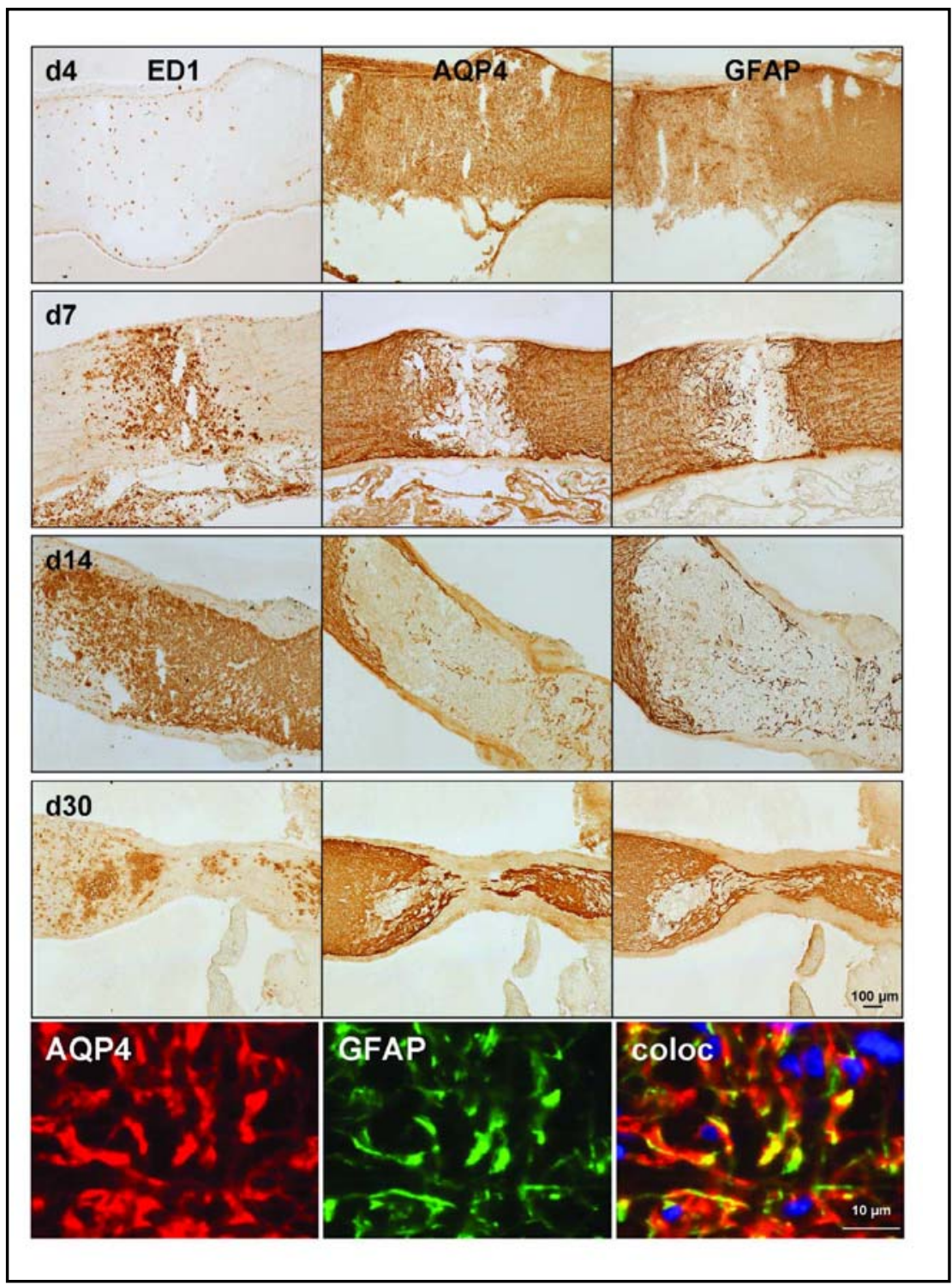

Constitutive expression of the water channel aquaporin 4 (AQP4) was essentially restricted to the ON with a more than 1000-fold higher expression in unlesioned ON compared to only marginal expression in the naïve SN. After crush injury no significant change occurred in the SN. Contrastingly, in the ON time course analysis by Q-PCR (Fig. 3) showed strong downregulation of AQP4 in the $\mathrm{ON}$ lesion at day 4 with gradual normalization within the subsequent 10 days.

The array analysis furthermore suggested contrasting patterns of tPA and UPA expression with TPA induction being specific for SN and UPA induction exclusively found in ON lesions (Table 2). In accordance with the array results, Q-PCR revealed strong upregulation of uPA mRNA in ON crush, but not in SN lesions (Fig. 4). Conversely, tPA mRNA was increased in the $\mathrm{SN}$, whereas it was actually downregulated in the ON lesion. Further time course analysis showed maximum induction of tPA in the $\mathrm{SN}$ and $\mathrm{uPA}$ in the $\mathrm{ON}$ lesion site at day 4 with a gradual return to normal levels 14 days after injury. As for the other ON-specific gene regulations, uPA induction in the $\mathrm{ON}$ was restricted to the crush site at all time points. Contrastingly, in the SN model, tPA also showed delayed upregulation in the distal nerve stump at 7 and 14 days after injury. The plasminogen activator inhibitor PAI-1 was constitutively expressed in the SN without significant regulation after injury, whereas it was upregulated at the lesion site in the ON (Table 2).

\section{Immunohistochemistry for aquaporin-4}

To corroborate our mRNA data at the protein level, we performed immunohistochemistry for AQP4 using a specific polyclonal antibody against rat AQP4 on longitudinal cryostat sections of crushed ON (Fig. 5). In unlesioned control ON, AQP4 immunoreactivity was mainly, if not exclusively, associated with astrocytes 
identified by anti-GFAP antibody labeling on serial sections. AQP4 expression by astrocytes was confirmed by double labeling immunofluorescence showing extensive coexpression of AQP4 and the GFAP marker. In crushinjured nerves, AQP4 staining disappeared in the lesion site at days 4 and 7 , paralleled by the disappearance of astrocytes and strong infiltration of macrophages seen on serial sections stained for the astrocyte marker GFAP or the macrophage antigen ED1. At days 14 and 30, AQP4 immunoreactivity was reexpressed on some astrocytes within the lesion site.

\section{Discussion}

Our comparison by cDNA array, Q-PCR, and immunohistochemistry represents the first systematic approach to the molecular response at the lesion site following crush injury to central vs. peripheral nerves in vivo. Previous gene expression studies have addressed gene expression in models of CNS injury without comparison to the corresponding PNS lesion condition [15]. Other genomic studies have mostly focused on molecular responses of neuronal cell bodies [1, 16-18] or distal nerve segments undergoing Wallerian degeneration [19-21], but have largely neglected the primary site of crush injury. This contrasts to experimental and clinical observations indicating that one major barrier to regenerating axons in CNS injury presents already at the primary injury site and that experimental strategies promoting axon growth across the injury site result in unimpeded axon extension through the distal fiber tract [22]. The comparison of molecular responses at the lesion site between the central and peripheral nervous system might therefore reveal new targets of therapeutic intervention enabling axon regeneration in CNS injury.

\section{Regulation of inflammatory genes}

Following localized injury to nerve fiber tracts, anterograde Wallerian degeneration of the nerve segment distal to the lesion occurs rapidly in the PNS but slowly and incompletely in the CNS. This is accompanied by early infiltration of the distal nerve stump by macrophages in the PNS whereas macrophages are only scarcely recruited during Wallerian degeneration in the CNS [23, 24]. In contrast, macrophage reactions at the primary lesion site occur vigorously and to a similar magnitude in both the CNS and PNS [25]. Accordingly, our present study revealed a similar extent of inflammatory gene induction at the lesion site in the crushed $\mathrm{ON}$ and $\mathrm{SN}$ with common upregulation of the CD53 antigen, C5a receptor and platelet-activating factor receptor involved in the chemoattraction and activation of leuko- and phagocytes. In line with previous results [26] we also found the proinflammatory cytokine IL-18 commonly upregulated, which is presumably caused by the infiltration of IL-18-positive macrophages. As an important exception from the otherwise similar induction of inflammatory gene products, we have previously shown that the cytokinelike protein osteopontin is exclusively expressed by macrophages in CNS, but not PNS crush lesions [27]. It is thus conceivable that at least at the time point studied in our present study there are more subtle differences in the molecular programming of lesion-associated macrophages in the CNS vs. PNS which might nevertheless have implications for the inhibition of axon outgrowth in CNS injury.

\section{Aquaporin 4 downregulation in the optic nerve lesion}

The water channel AQP4 was strongly expressed by astrocytes in the naïve $\mathrm{ON}$ in contrast to an only marginal expression in the SN. Crush injury induced a profound downregulation of $\mathrm{AQP} 4$ restricted to the $\mathrm{ON}$ lesion with lowest levels reached at day 4 and gradual normalization thereafter. This was paralleled by the disappearance of GFAP-positive astrocytes (Fig. 3) from the ON lesion. Thus, the loss of AQP4 occurred as a consequence of severe local CNS injury leading to a loss of astrocytes from the lesion site. These findings are in line with previous studies showing transient disappearance of astrocytes and downregulation of AQP4 in various CNS lesion models $[28,29]$. In spinal cord injury, AQP4 downregulation was suggested to worsen vasogenic oedema formation [30]. On the other hand, AQP4 knockout mice had a functional benefit after spinal cord injury [31] suggesting a neuroprotective effect of AQP4 downregulation. In human glioma AQP4 expression was associated with vasogenic oedema formation but seemed not neuroprotective [32]. Our immunohistochemistry at day 30 showed that the scarring ON lesion was partly repopulated by AQP4- and GFAP-positive astrocytes. Interestingly, recent studies point to a role of AQP4 in astrocyte migration and glial scar formation by facilitating cytoskeleton cell changes [33, 34]. AQP4 expression is also lost in severe necrotic and cavitary multiple sclerosis and infarct lesions [35]. Recently AQP4 autoantibodies were discovered as a diagnostic marker for Neuromyelitis optica [36] and passive transfer studies suggested a critical relevance of the autoantibodies for disease

Zickler/Küry/Gliem/Hartung/Jander 
pathogenesis [37, 38].

\section{Growth factor related gene regulation}

Apart from a similar upregulation of transforming growth factor (TGF)-beta in both systems, we found a selective upregulation of the glial cell line-derived neurotrophic factor receptor (GDNFR) alpha in the SN but not ON model. Previous studies have shown that GDNFR-alpha becomes trophically active only by TGFbeta mediated transport to the cell membrane [39]. In other systems TGF-beta 1 increases on a transcriptional level the expression of neurotrophic insulin-like growth factor (IGF-I) and its binding proteins (IGFBP) [40]. Interestingly, we found that these genes were differentially regulated with selective upregulation of IGFBP-3 in the $\mathrm{SN}$ and of IGF-I in the ON crush lesion. Beyond the modulation of IGF activities IGFBPs exert pleiotropic IGFindependent signaling effects via integrin receptors and are involved in transcriptional regulation [41]. Of note, IGFBP-3 downregulates the mRNA expression of uPA independently of the IGF-I receptor [42]. In contrast, IGFI upregulates uPA [43]. The differential regulation patterns suggest crossregulatory effects of growth factors on proteases involved in tissue remodeling after nerve injury which might at least partially explain the differential regulation of tPA and uPA observed in our present study (Fig. 4).

\section{Differential plasminogen activator regulation}

Proteolysis by activation of plasminogen [8] and matrix metalloproteinases [44] is an essential prerequisite for growth cone extension and axonal outgrowth through regeneration inhibiting components of the injury site, adhesive inflammatory cells, debris and structurally altered extracellular matrix. Our results reveal differential regulation of the two main plasminogen activators with a selective upregulation of UPA in the ON and IPA in the $\mathrm{SN}$ lesion. In the SN tPA is expressed in regenerating axons and Schwann cells and axonal regeneration is delayed in knock out mice for tPA, uPA and plasminogen $[45,46]$. In line with our results it has been shown that beneficial fibrinolysis after SN crush is mainly tPA mediated [47]. Of note, in these studies the expression of PAI-I remained unchanged which further underscores our findings of a constitutive PAI-I expression in the SN without significant regulation. Our results furthermore showed a delayed upregulation in the distal nerve stump at days 7 and 14 after injury which probably reflects the proceeding of the regrowing axon. Contrastingly, in the ON we found a mild downregulation for tPA while PAI-

Local Gene Regulation in Nerve Regeneration
I and uPA were upregulated with restriction to the lesion site. This differential regulation pattern might be mediated by the p 75 neurotrophin receptor which is expressed in normal and crush injured ON $[48,49]$ and was recently shown to downregulate tPA independent of neurotrophin signaling while it upregulates PAI-I expression and leaves uPA activity unaffected [50]. Evidence from facial nerve axotomy likewise points to the induction of UPA rather than tPA in CNS injury [51] but the specific role of uPA in CNS nerve regeneration has not been comprehensively studied. Numerous findings in heart [52], vessels [53], skin [54], and other peripheral organs [55] indeed suggest differential involvement of UPA and tPA in wound healing with fibrogenic responses mainly exerted via uPA. Thus the differential expression of uPA and tPA might be relevant for tissue remodeling following CNS and PNS injury and may represent a new therapeutic target for recently developed specific uPA inhibitors [56].

\section{Local upregulation of neuronal $m R N A$}

Unexpectedly, our array analysis revealed lesionassociated mRNA upregulation for genes of likely neuronal origin such as NPY, TRH and thymosin-beta 15 . As the neuronal cell bodies are remotely located these mRNAs must be expressed in either glial cells or axons. The latter would be in line with several demonstrations of mRNA transportation from the neuronal soma to the axon and extrasomatic mRNA translation in the axon [57]. The presence of local mRNA bypasses the somatic production of too complex or toxic proteins and their rather slow axonal transport. Furthermore, injury-induced local mRNA translation is involved in retrograde signaling from the lesion to the neuron [58] and growth cone formation as a prerequisite for axon regeneration requires active local protein synthesis and proteolysis $[59,60]$.

Our array analysis revealed a more extensive induction of mRNAs associated with transcription and translation including ribosomal proteins in the $\mathrm{SN}$ in line with immunolocalization studies showing almost undetectable ribosomal protein levels in axotomized adult ONs in contrast to abundant levels in cut peripheral sensory axons [60]. We found that thymosin-beta 15 (Tb15) was specifically increased in the SN lesion site. The three thymosin isoforms beta 4,10 and 15 are small actin-binding proteins with multiple cell type-specific functions. Tb15 is the isoform most specific to the nervous system [61]. In adult rats, Tb15 is found in postmitotic migratory neurons and is induced after cerebral ischemia presumably reflecting axonal sprouting [62]. Interestingly, adult Zebrafish retinal ganglion cells that in contrast to 
mammals restore functional axon connections after $\mathrm{ON}$ lesions, showed thymosin-beta mRNA at the lesion site with a maximal expression at day 4 and a distal shift along the axon which correlates temporally with the progression of growth cones and did not colocalize with macrophages [63]. Furthermore, studies in the mollusc Aplysia indicate that thymosin-beta is locally synthesized in regenerating axons following axotomy [64]. Thymosin-beta promotes axonal branch formation in developing rat brain [65]. In development, suppression of thymosin-beta by siRNA reduces branching [65] and results in malformation of axonal tracts in Zebrafish [66] while it enhances elongation of outgrowing neurites in young snail neurons [67]. The contradictory effects observed in developing and regenerating neurons might relate to species- or modeldependent differences but could also indicate that an adapted local regulation of thymosin-beta is required for optimal axon regeneration. Recently extracellular ligands such as neurotrophins and myelin components were shown to locally up- or downregulate axonal mRNAs in adult axons [68]. Our results of a specific Tb15 upregulation in the $\mathrm{SN}$ lesion underscores its relevance in adult rat axonal regeneration and is probably of local axonal origin.

Our finding of a strong local upregulation of neuropeptides such as NPY and TRH in the ON lesion further underscores an active participation of axons in the local gene expression at site of nerve fiber injury. TRH and analogues were shown to have neuroprotective properties in traumatic brain and spinal cord injury and to modulate posttraumatic mRNA expression. Of note, TRH has been reported to downregulate aquaporin 4 mRNA [69]. The cellular source of TRH in the lesioned CNS is unknown. Retinal cells and ON axons of amphibians are TRH immunoreactive [70], but little is known about TRH expression in mammalian ONs. Although TRH mRNA expression has been observed in astroglial cells of adult rat spinal cord [71] our immunohistochemical results indicate that astrocytes are probably not the source of TRH expression because they progressively disappeared from the crush lesion. Thus, the TRH
mRNA in the ON lesion is likely to be of axonal origin.

\section{Conclusion}

Our comparative approach to lesion-associated gene expression in optic and sciatic nerve crush injury highlights a potential role of differential growth factor, water channel, and plasminogen activator gene expression for an either hostile or supportive microenvironment for axonal regeneration. An unexpectedly strong participation of putative axonally localized mRNAs was found and represent potential therapeutic targets for local RNA interference recently shown to be effective in mammalian peripheral axons [72]. The functional and potential therapeutic implications of local gene regulations at sites of nerve injury are still incompletely understood and warrant further study.

\section{Abbreviations}

AQP4 (aquaporin 4); CNS/PNS (central/peripheral nervous system); GDNFR (glial cell line-derived neurotrophic factor receptor); GFAP (glial fibrillary acidic protein); IGF (insulin-like growth factor); IGFBP (IGFbinding protein); IL (interleukin); ON (optic nerve); PAI (plasminogen activator inhibitor); Q-PCR (quantitative real-time polymerase chain reaction); $\mathrm{SN}$ (sciatic nerve); tPA/uPA (tissue/urokinase-type plasminogen activator); TGF (transforming growth factor); Tb15 (thymosin-beta 15); TRH (thyrotropin-releasing hormone); NPY (neuropeptide $\mathrm{Y}$ ).

\section{Acknowledgements}

We thank B. Blomenkamp and S. Hamm for excellent technical assistance. This study was supported by a grant of the Düsseldorf University Research Fund to SJ.

\section{References}

Bareyre FM, Schwab ME: Inflammation, >2 degeneration and regeneration in the injured spinal cord: insights from DNA microarrays. Trends Neurosci 2003;26:555-563.
David S, Lacroix S: Molecular $>3$ approaches to spinal cord repair. Annu Rev Neurosci 2003;26:411-440.
Trapp BD, Peterson J, Ransohoff RM, Rudick R, Mork S, Bo L: Axonal transection in the lesions of multiple sclerosis. N Engl J Med 1998;338:278285 . 
-4 Ferguson B, Matyszak MK, Esiri MM, Perry VH: Axonal damage in acute multiple sclerosis lesions. Brain 1997;120:393-399.

-5 Harel NY, Strittmatter SM: Can regenerating axons recapitulate developmental guidance during recovery from spinal cord injury? Nat Rev Neurosci 2006;7:603-616.

-6 David S, Aguayo AJ: Axonal elongation into peripheral nervous system "bridges" after central nervous system injury in 20 adult rats. Science 1981;214:931-933.

7 Schwab ME: Increasing plasticity and functional recovery of the lesioned spinal cord. Prog Brain Res 2002;137:351-359.

8 Chen ZL, Yu WM, Strickland S: Peripheral regeneration. Annu Rev Neurosci 2007;30:209-233.

-9 Vargas ME, Barres BA: Why is Wallerian degeneration in the CNS so slow? Annu Rev Neurosci 2007;30:153-179.

$\checkmark 10$ Küry $\mathrm{P}$, Schroeter M, Jander S: Transcriptional response to circumscribed cortical brain ischemia: spatiotemporal patterns in ischemic vs. 22 remote non-ischemic cortex. Eur J Neurosci 2004;19:1708-1720.

-11 Küry P, Greiner-Petter R, Cornely C, Jurgens T, Müller HW: Mammalian achaete scute homolog 2 is expressed in the adult sciatic nerve and regulates the expression of Krox24, Mob-1, CXCR4, and p57kip2 in Schwann cells. J Neurosci 2002;22:7586-7595.

-12 Jander S, Schroeter M, Stoll G: Interleukin-18 expression after focal ischemia of the rat brain: association with the late-stage inflammatory response. J Cereb Blood Flow Metab 2002;22:62-70.

$\checkmark 13$ Trapp BD, Hauer P, Lemke G: Axonal regulation of myelin protein mRNA levels in actively myelinating Schwann cells. J Neurosci 1988;8:3515-3521.

14 Kim DS, Choi JO, Rim HD, Cho HJ: Downregulation of voltage-gated potassium channel alpha gene expression in dorsal root ganglia following chronic constriction injury of the rat sciatic nerve. Brain Res Mol Brain Res 2002;105:146-152.

$\checkmark 15$ Carmel JB, Galante A, Soteropoulos P, Tolias P, Recce M, Young W, Hart RP: Gene expression profiling of acute spinal cord injury reveals spreading inflammatory signals and neuron loss. Physiol Genomics 2001;7:201-213.

16 Fan M, Mi R, Yew DT, Chan WY: Analysis of gene expression following sciatic nerve crush and spinal cord hemisection in the mouse by microarray expression profiling. Cell Mol Neurobiol 2001;21:497-508.

$\$ 17$ Küry P, Abankwa D, Kruse F, GreinerPetter R, Müller HW: Gene expression profiling reveals multiple novel intrinsic and extrinsic factors associated with axonal regeneration failure. Eur $\mathbf{J}$ Neurosci 2004;19:32-42.
Szpara ML, Vranizan K, Tai YC, Goodman CS, Speed TP, Ngai J: Analysis of gene expression during neurite outgrowth and regeneration. BMC Neurosci 2007;8:100. Bosse F, Hasenpusch-Theil K, Küry P, Müller HW: Gene expression profiling reveals that peripheral nerve regeneration is a consequence of both novel injury-dependent and reactivated developmental processes. J Neurochem 2006;96:1441-1457.

Heumann R, Lindholm D, Bandtlow C, Meyer M, Radeke MJ, Misko TP, Shooter E, Thoenen H: Differential regulation of mRNA encoding nerve growth factor and its receptor in rat sciatic nerve during development, degeneration, and regeneration: role of macrophages. Proc Natl Acad Sci U S A 1987;84:8735-8739. Perrin FE, Lacroix S, Aviles-Trigueros M, David S: Involvement of monocyte chemoattractant protein-1, macrophage inflammatory protein-1alpha and interleukin-1beta in Wallerian degeneration. Brain 2005;128:854-866. Davies SJ, Fitch MT, Memberg SP, Hall AK, Raisman G, Silver J: Regeneration of adult axons in white matter tracts of the central nervous system. Nature 1997;390:680-683.

23 Stoll G, Griffin JW, Li CY, Trapp BD: Wallerian degeneration in the peripheral nervous system: participation of both Schwann cells and macrophages in myelin degradation. J Neurocytol 1989;18:671683.

Stoll G, Trapp BD, Griffin JW: Macrophage function during Wallerian degeneration of rat optic nerve: clearance of degenerating myelin and Ia expression. J Neurosci 1989;9:2327-2335.

Jander S, Lausberg F, Stoll G: Differential recruitment of $\mathrm{CD} 8+$ macrophages during Wallerian degeneration in the peripheral and central nervous system. Brain Pathol 2001;11:27-38.

26 Menge T, Jander S, Stoll G: Induction of the proinflammatory cytokine interleukin-18 by axonal injury. $\mathrm{J}$ Neurosci Res 2001;65:332-339.

Küry P, Zickler P, Stoll G, Hartung HP, Jander S: Osteopontin, a macrophagederived matricellular glycoprotein, inhibits axon outgrowth. Faseb J 2005;19:398-400.

Blaugrund E, Duvdevani R, Lavie V, Solomon A, Schwartz M: Disappearance of astrocytes and invasion of macrophages following crush injury of adult rodent optic nerves: implications for regeneration. Exp Neurol 1992;118:105-115.

Frank M, Wolburg H: Cellular reactions at the lesion site after crushing of the rat optic nerve. Glia 1996;16:227-240.
Nesic O, Lee J, Ye Z, Unabia GC, Rafati D, Hulsebosch CE, Perez-Polo JR: Acute and chronic changes in aquaporin 4 expression after spinal cord injury. Neuroscience 2006;143:779-792.

-31 Saadoun S, Bell BA, Verkman AS, Papadopoulos MC: Greatly improved neurological outcome after spinal cord compression injury in AQP4-deficient mice. Brain. 2008;131:1087-98

32 Warth A, Simon P, Capper D, Goeppert B, Tabatabai G, Herzog H, Dietz K, Stubenvoll F, Ajaaj R, Becker R, Weller M, Meyermann R, Wolburg $\mathrm{H}$, Mittelbronn M: Expression pattern of the water channel aquaporin-4 in human gliomas is associated with blood-brain barrier disturbance but not with patient survival. J Neurosci Res 2007;85:13361346.

-33 Auguste KI, Jin S, Uchida K, Yan D, Manley GT, Papadopoulos MC, Verkman AS: Greatly impaired migration of implanted aquaporin-4-deficient astroglial cells in mouse brain toward a site of injury. Faseb J 2007;21:108-116. Nicchia GP, Srinivas M, Li W, Brosnan CF, Frigeri A, Spray DC: New possible roles for aquaporin-4 in astrocytes: cell cytoskeleton and functional relationship with connexin43. Faseb J 2005;19:16741676 .

35 Roemer SF, Parisi JE, Lennon VA, Benarroch EE, Lassmann H, Bruck W, Mandler RN, Weinshenker BG, Pittock SJ, Wingerchuk DM, Lucchinetti CF: Pattern-specific loss of aquaporin-4 immunoreactivity distinguishes neuromyelitis optica from multiple sclerosis. Brain 2007;130:1194-1205.

36 Lennon VA, Kryzer TJ, Pittock SJ, Verkman AS, Hinson SR: IgG marker of optic-spinal multiple sclerosis binds to the aquaporin-4 water channel. J Exp Med 2005;202:473-477.

-37 Bennett JL, Lam C, Kalluri SR, Saikali P, Bautista K, Dupree C, Glogowska M, Case D, Antel JP, Owens GP, Gilden D, Nessler S, Stadelmann C, Hemmer B: Intrathecal pathogenic anti-aquaporin-4 antibodies in early neuromyelitis optica. Ann Neurol. 2009;66:617-629.

-38 Bradl M, Misu T, Takahashi T, Watanabe M, Mader S, Reindl M, Adzemovic M, Bauer J, Berger T, Fujihara K, Itoyama Y, Lassmann H: Neuromyelitis optica: pathogenicity of patient immunoglobulin in vivo. Ann Neurol 2009;66:630643.

Peterziel H, Unsicker K, Krieglstein K: TGFbeta induces GDNF responsiveness in neurons by recruitment of GFRalphal to the plasma membrane. J Cell Biol 2002;159:157-167. 
40 Kveiborg M, Flyvbjerg A, Eriksen EF Kassem M: Transforming growth factorbetal stimulates the production of insulin-like growth factor-I and insulinlike growth factor-binding protein-3 in human bone marrow stromal osteoblast progenitors. J Endocrinol 2001;169:549561 .

-41 Mohan S, Baylink DJ: IGF-binding proteins are multifunctional and act via IGF-dependent and -independent mechanisms. J Endocrinol 2002;175:1931 .

42 Oh SH, Lee OH, Schroeder CP, Oh YW, Ke S, Cha HJ, Park RW, Onn A, Herbst RS, Li C, Lee HY: Antimetastatic activity of insulin-like growth factor binding protein-3 in lung cancer is mediated by insulin-like growth factor-independent urokinase-type plasminogen activator inhibition. Mol Cancer Ther 2006;5:2685-2695

43 Dunn SE, Torres JV, Oh JS, Cykert DM Barrett JC: Up-regulation of urokinasetype plasminogen activator by insulinlike growth factor-I depends upon phosphatidylinositol-3 kinase and mitogen-activated protein kinase kinase. Cancer Res 2001;61:1367-1374.

44 Pizzi MA, Crowe MJ: Matrix $\$ 54$ metalloproteinases and proteoglycans in axonal regeneration. Exp Neurol 2007;204:496-511.

45 Siconolfi LB, Seeds NW: Mice lacking $>5$ tPA, uPA, or plasminogen genes showed delayed functional recovery after sciatic nerve crush. J Neurosci 2001;21:43484355 .

46 Siconolfi LB, Seeds NW: Induction of the plasminogen activator system accompanies peripheral nerve regeneration after sciatic nerve crush. J $>56$ Neurosci 2001;21:4336-4347.

47 Akassoglou K, Kombrinck KW, Degen JL, Strickland S: Tissue plasminogen activator-mediated fibrinolysis protects against axonal degeneration and demyelination after sciatic nerve injury. 57 J Cell Biol 2000;149:1157-1166.

48 Moalem G, Gdalyahu A, Shani Y, Otten U, Lazarovici P, Cohen IR, Schwartz M: Production of neurotrophins by activated $\mathrm{T}$ cells: implications for neuroprotective autoimmunity. J Autoimmun 2000;15:331-345.

49 Starkey GD, Petratos S, Shipham KA, Butzkueven H, Bucci T, Lowry K, Cheema SS, Kilpatrick TJ: Neurotrophin receptor expression and responsiveness by postnatal cerebral oligodendroglia. Neuroreport 2001;12:4081-4086.
Sachs BD, Baillie GS, McCall JR, Passino MA, Schachtrup C, Wallace DA, Dunlop AJ, MacKenzie KF, Klussmann E, Lynch MJ, Sikorski SL, Nuriel T, Tsigelny I, Zhang J, Houslay MD, Chao MV, Akassoglou K: p75 neurotrophin receptor regulates tissue fibrosis through inhibition of plasminogen activation via a PDE4/ cAMP/PKA pathway. J Cell Biol 2007;177:1119-1132.

Nakajima K, Reddington M, Kohsaka S, Kreutzberg GW: Induction of urokinasetype plasminogen activator in rat facial nucleus by axotomy of the facial nerve. J Neurochem 1996;66:2500-2505.

52 Moriwaki H, Stempien-Otero A, Kremen M, Cozen AE, Dichek DA: Overexpression of urokinase by macrophages or deficiency of plasminogen activator inhibitor type 1 causes cardiac fibrosis in mice. Circ Res 2004;95:637-644.

Parfyonova Y, Plekhanova O, Solomatina M, Naumov V, Bobik A, Berk B, Tkachuk V: Contrasting effects of urokinase and tissue-type plasminogen activators on neointima formation and vessel remodelling after arterial injury. J Vasc Res 2004;41:268-276.

Schäfer BM, Maier K, Eickhoff U, Todd $\mathrm{RF}$, Kramer MD: Plasminogen activation in healing human wounds. Am J Pathol 1994;144:1269-1280.

Bugge TH, Flick MJ, Danton MJ, Daugherty CC, Romer J, Dano K, Carmeliet P, Collen D, Degen JL: Urokinase-type plasminogen activator is effective in fibrin clearance in the absence of its receptor or tissue-type plasminogen activator. Proc Natl Acad Sci U S A 1996;93:5899-5904.

Zhu M, Gokhale VM, Szabo L, Munoz RM, Baek H, Bashyam S, Hurley LH, Von Hoff DD, Han H: Identification of a novel inhibitor of urokinase-type plasminogen activator. Mol Cancer Ther 2007;6:1348-1356

7 Lin AC, Holt CE: Local translation and directional steering in axons. Embo $\mathrm{J}$ 2007;26:3729-3736

>58 Hanz S, Perlson E, Willis D, Zheng JQ, 70 Massarwa R, Huerta JJ, Koltzenburg M, Kohler M, van-Minnen J, Twiss JL, Fainzilber M: Axoplasmic importins enable retrograde injury signaling in lesioned nerve. Neuron 2003;40:10951104.

59 Willis DE, Twiss JL: The evolving roles of axonally synthesized proteins in regeneration. Curr Opin Neurobiol 72 2006;16:111-118

60 Verma P, Chierzi S, Codd AM, Campbell DS, Meyer RL, Holt CE, Fawcett JW: Axonal protein synthesis and degradation are necessary for efficient growth cone regeneration. J Neurosci 2005;25:331342 .
Sun W, Kim H: Neurotrophic roles of the beta-thymosins in the development and regeneration of the nervous system. Ann N Y Acad Sci 2007;1112:210-218. Kim Y, Kim EH, Hong S, Rhyu IJ, Choe J, Sun W, Kim H: Expression of thymosin beta in the rat brain following transient global ischemia. Brain Res 2006;1085:177-182.

63 Roth LW, Bormann P, Wiederkehr C, Reinhard E: Beta-thymosin, a modulator of the actin cytoskeleton is increased in regenerating retinal ganglion cells. Eur J Neurosci 1999;11:3488-3498.

-64 Colby GP, Sung YJ, Ambron RT: mRNAs encoding the Aplysia homologues of fasciclin-I and beta-thymosin are expressed only in the second phase of nerve injury and are differentially segregated in axons regenerating in vitro and in vivo. J Neurosci Res 2005;82:484498.

Choe J, Sun W, Yoon SY, Rhyu IJ, Kim EH, Kim H: Effect of thymosin beta 15 on the branching of developing neurons. Biochem Biophys Res Commun 2005;331:43-49.

Roth LW, Bormann P, Bonnet A, Reinhard E: beta-thymosin is required for axonal tract formation in developing zebrafish brain. Development 1999;126:1365-1374.

67 van Kesteren RE, Carter C, Dissel HM, van Minnen J, Gouwenberg Y, Syed NI, Spencer GE, Smit AB: Local synthesis of actin-binding protein beta-thymosin regulates neurite outgrowth. J Neurosci 2006;26:152-157.

Willis DE, van Niekerk EA, Sasaki Y, Mesngon M, Merianda TT, Williams GG, Kendall M, Smith DS, Bassell GJ, Twiss JL: Extracellular stimuli specifically regulate localized levels of individual neuronal mRNAs. J Cell Biol 2007; 178:965-980.

Faden AI, Movsesyan VA, Knoblach SM, Ahmed F, Cernak I: Neuroprotective effects of novel small peptides in vitro and after brain injury. Neuropharmacology 2005;49:410-424. Anadon R, Luz Diaz M, Becerra M, Jesus Manso M: Presence of thyrotropinreleasing-hormone-immunoreactive (TRHir) amacrine cells in the retina of anuran and urodele amphibians. Brain Res 2002;926:86-93.

Fernandez-Agullo T: Thyrotropinreleasing hormone and its receptor in glia. Glia 2001;33:267-276.

Murashov AK, Chintalgattu V, Islamov RR, Lever TE, Pak ES, Sierpinski PL, Katwa LC, Van Scott MR: RNAi pathway is functional in peripheral nerve axons. Faseb J 2007;21:656-670. 